\title{
Overcoming Stuttering Using Delayed Auditory Feedback (DAF): A Case Study
}

\author{
Sadeq Ali Saad Al-Yaari (Corresponding author) \\ Independent Researcher, Dept. of English, College of Arts, King Saud University (KSU) \\ Riyadh, Kingdom of Saudi Arabia. E-mail: prof.sadeq@gmail.com
}

FayzaSaleh Al Hammadi

Associate prof., Dept. of English, College of Arts, King Faisal University, Al-Hassa

Kingdom of Saudi Arabia. E-mail: viceii.library@kfu.edu.sa

\begin{abstract}
Salah Ayied Alyami
Assistant professor, Dept. of English, Dammam College of Technology, Dammam University Riyadh, Kingdom of Saudi Arabia. E-mail: salah1sa@yahoo.com
\end{abstract}

Nassr Almaflehi

A professor of Statistics, College of Applied Medical Sciences, King Saud University (KSU) Riyadh, Kingdom of Saudi Arabia. E-mail: nassr_almaflehi@hotmail.com

Received: January 1, 2013 Accepted: January 10, 2013 Published: January 17, 2013 doi:10.5296/ijele.v1i2.3061 URL: http://dx.doi.org/10.5296/ijele.v1i2.3061

\begin{abstract}
Background: With the tremendous improvements in technology in producing new techniques to overcome stuttering, many assumptions were stated from different aspects.

Aims: To in/validate some of the stuttering assumptions, the present study attempts to investigate the role played by Delayed Auditory Feedback (DAF) device in overcoming stuttering and improving stutterers' fluency.
\end{abstract}

Methods: A client study of MO, a 23-year old bilingual student who exhibits stuttering and 
language delay due to psychological factors. An intensive therapeutic treatment which continued for 20 months has been given to the client at hand. The client had to practice (in English) ten(10) alphabetical characters, twenty (20) words (10 nouns and 10 verbs), and ten (10)sentences for four continuous hours every day.

Results: The analyses of the client's utterances throughout five entire sessions show that his rate of speech became slower if not almost normal across increases in DAF. The findings reveal that simultaneous application of both treatments on speaking through DAF was successful in reducing the rate of stuttering in the speech of the client under investigation. It all depends on age, determination, the level of severity, and the way he/she uses DAF. These findings account for the results that support many theories of stuttering including Phonemic Content Theory, Covert Repair Hypothesis (CRH) and Johnson's theory. Taken together, these results weigh strongly against the hypothesis stated that stutterers have generally high levels of emotional reactivity (e.g., Brutten/Shoemaker, 1967).

Keywords: Stuttering, Overcome Delay, Auditory, Feedback, Case Study 


\section{Introduction}

In the dictionary, the infinitive "to stutter" means "to speak or utter with a spasmodic repetition or prolongation of sounds." (Longman, 1995).Otto (1932) defines it as " the utterance of a sound unit, syllable or word, made faulty by severance, extension or repetition of initial sound" (Sheehan, 1970, P.40). In fact, the word "repetition" here may mislead an untrained researcher who may mix the term "stuttering" with the term "disfluency" while the fact is that "disfluency" refers, according to Johnson, (1942) to "Sounds' interjections and prolongation, part word/word/sentence repetition, revision, broken and/or incomplete words, phrases, etc. " (Peterson \& Marquardt, 1981, P.218)

Unfortunately, there is shortage of information concerning percentages of stutterers in the Arab world unlike the case in the U.S, for example, where survey studies show that the percentage of speech disorders among people is 5\% (Kirk, 1993), and 1-3\% among students, whereas $1-2 \%$ of students suffer from voice disorders (Milhim, 2002), 1\% suffer from stuttering (Heward, 1992). The study of Abu Ghazālah \& Jaradāt (1986) shows that there isonly 94 clients in all Jordanian schools in the academic year 1982/1983.

As a discipline, stuttering has occurred in the 20th century, but as an issue, it has started earlier than that. It was in the 19th century when it was first defined (Wyllie, 1894), divided (Treitel, 1898), differentiated (Blume, 1933) and finally described (Borel \& Maissonny, 1937). However, throughout the previous century, psychoneurolinguists were attempting to identify whether or not there is a feedback associated with stuttering (Lee, 1950a, 1950b; Fairbanks, 1955; Stromsta, 1957; Chase, 1958; Guttman, 1960; Neelley, 1961; Johnson, 1961a). According to some neurolinguists, this feedback could be positive or negative and both types depend on the stutterer's background. For example, Skinner (1953) considers "punishment" as a negative behavior as it is "in the long run an effective instrument for the control of behavior." (Skinner, 1953, P.133)

A question like: "When does Stuttering occur?" remains unanswered. It could happen at any age, especially when language is acquired i.e., before five or eight (Merely, 1957).Right after a year of introducing DAF by technology developers to individuals suffering from stuttering, the device received high criticism. Psychoneurolinguists concentrated on the drawbacks of the new technique which, according to them, might disrupt the speaking fluency (Fairbanks, \& Guttman, 1958, PP.12-22). Of course, this does not stop some psychoneurolinguists from recommending it as a useful technique for treatment (Goldiamond, 1965). For that matter, new theories and hypotheses were starting to release. Phonemic content hypothesis stated that the content of the delayed feedback signal interferes with the actual production of a particular speech unit. Supporters of Covert Repair Hypothesis (CRH) claim that stuttering individuals have had a predisposition to its occurrence or to a breakdown in speech. Followers of Johnson's theory of stuttering are of the view that children who are penalized for normal non fluencies are likely to develop stuttering and that adults differ in their standards of fluency. Taken together, these results weigh strongly against the hypothesis that stutterers have generally high levels of emotional reactivity (e.g., Brutten/Shoemaker, 1967). However, as time passes, DAF proved itself as one of the most useful devices for stutterers. It is found to 
affect reading less when the words read formed sentences than when these words were randomly arranged (Dalrymple-Alford, 1973).

The role of feedback mechanism in speech production and the lack of some devices that may help stutterers overcome their stuttering have caught an attention in the last few decades (Ringel \& Sheer, 1963; Scott \& Ringel, 1971; Gammon et al., 1971; Horii et al., 1973; Hardcastle, 1975). Some psychoneurolinguists believed that talking under conditions of DAF will be considered aversive (Flanagan et al.,1958,1959), and terminating this aversive condition is only by showing down and prolonging each utterance as this could guarantee the privilege of DAF on other programs like Perkins'(1969) (Eisenson,1975, PP.273-275). In his research titled: "Operant Conditioning and stuttering", published in 1975, Prof. Shames talks about two stutterers who used DAF. The speech of the first client improved to 150 words per minute and the client had passed beyond his criteria of talking without stuttering for 5 minutes on each of eleven (11) topics of conversation at each of the delay intervals through zero delay. The second client conversed freely for five (5) minutes without stuttering, but he had, according to Prof. Shames, to go back on the DAF to the next-shorter delay interval (Eisenson, 1975, PP. 278-9). Such results drew the attention of some psychoneurolinguists who emphasized the importance of childhood period as it is, according to them, a probable period through which stuttering emerges (Rieber et al., 1976).

As a matter of fact, DAF as a means of treatment is not restricted to children, adults can also benefit from it. It all depends on the way it is used and, more importantly, the motivation the stutterer receives. To that end, Van Riper (1973) states:

"....The enhancement ... is emphasized utilizing auditory masking, DAF..." (Gregory, 1979, P.3)Motivation is important because some stutterers become "extremely angry when he became fluent in only one (1) day of programmed DAF therapy." (ibid. P. 143)

Explaining the simplicity in using DAF, Byrne (1983) enhances clients by stating:

"With DAF, the speaker talks into a microphone, a machine records his speech and this is then feeds back to him through earphones a fraction of a second after it would normally be heard." Byrne, 1983, P.78). After Fairbanks' Feedback Theory of Speech, attention has been focused on the possibilities of inventing a device that ends the suffering of stutterers forever. Basically, the idea of inventing new technique had started in the late 19th century because of the lack of motor programs and feedback. It began first as a concept (James, 1890; Lashley, 1917, 1951; Henry \& Rogers, 1960; and Lazlo, 1967), and then the concept was developed into theories (Schmidt, 1975, 1982a; Keele, 1982; Inhof \& Gordon, 1984; Stenberg et al., 1978). Having DAF presented to the situation, the stuttering frequency subsequently drops and everybody, according to Eisenson (1975), assumes that the stimulus must have constituted "punishment" or "improvement" as stimilus has been thoroughly tested and criticized later on by number of neurologists (Hilgard, 1948, 1956; Solomon \& Brush, 1956; Sheehan, 1970a, 1970b; Hessell, 1971; Van Riper, 1973).

However, remarkable details in addition to some developments were presented elsewhere (Bordon, 1979; Gracco, 1984; Geacco \& Abbs, in press, a). The reaction to such 
developments varied from those who are against the role of sensors in the guidance of movements (Taub\& Berman, 1968; Fentress, 1979; Polit \& Bizzi, 1979) and those who think that movements carried out in some places are often only grossly normal and require rather simple or stereotypic tasks (Bossom, 1974; Polit \& Bizzi, 1979; Rothwell et al., 1982; Sanes $\&$ Evarts, 1983). However, those who adopted the idea that sensorimotor mechanism has the requisite characteristics to be used in the control and co-ordination of speech (Folkins \& Abbs, 1975; Abbs \& Gracco, 1984; Kelso et al., 1984; Shaiman et al., 1985; Gracco \& Abbs; 1985, 1987). The idea of sensorimotor mechanism has been later enriched by Lane \& Tranel (1971) and Neilson \& Neilson (1985). Finally, the dream came true by inventing DAF as a device that enhances the stutterer to practice and control his/ her voice.

Nor must we forget here to distinguish stuttering from disfluency. While the former is characterized by changeable behavior including hesitation, circumlocution in terms of repetition, sound prolongation, etc., the latter is characterized by the lack of being shrewd(skillful) in producing oral or written language in terms of speech segments including single sounds, syllables, etc. (Andrews et al., 1983; and Wall, 1988). Some psychoneurolinguists believe that that stutterers experience enhancement of fluency while speaking under delayed auditory feedback (DAF) at a fast articulatory rate, be viewed as an anomaly (Stuart, 1996). In his thesis, Tellis (1996) discussed the efficacy of the computer-aided fluency establishment trainer (CAFET) on treating stuttering. The researcher admits that there are some other devices that can treat stuttering beyond training with the CAFET. According to the researcher, a combination of the CAFET and self-monitoring of fluency skills, according to the researcher, is worth investigating.

Until the end of the previous century, it was believed by some specialists in general and psychoneurolinguists in particular that stuttering cannot be treated especially for children above 12 years old. As Blood (1998) states: "There is no medication for the stuttering as it persists after 12 years of age.” (Pholips\&Ruscello, 1998, P. 163)

In fact, Blood's statement might be true in terms of medication, not as a therapeutic technique. It is important to point out here that many psychoneurolinguists in the field have tried alternative methods including some devices hoping that one of them may achieve results similar to those of DAF. In their study titled: "Treating stuttering in young children: Predicting treatment time in the Lidcombe program", Jones et al., (2000) found that for a child with the Lidcombe program; the time of recovery may decrease with the period since onset. Their data provide evidence that a delay in treatment of early stuttering during the preschool years will not worsen the tractability of the condition, at least in terms of the treatment time required. Commenting on that, the team state:

"There are three important caveats to these data. First, these findings relate to the first stage of the Lidcombe Program only, and say nothing about treatment outcome in the long term. Second, the findings pertain only to children in the first few years after onset of stuttering and cannot be generalized to later childhood or early adolescence. Third, the present findings pertain to one treatment method only." (Jones et al., 2000, P. 1440)

Strictly speaking, stutterers' suggestions plus brilliant ideas proposed by Speech Language 
Pathologists/ Therapists (SLP/Ts) in addition to the great efforts made by psychoneurolinguists who were attempting to document plethora of theories on stuttering (Hahn, 1956; Riper, 1971; Eisenson, 1975; Rieber et al., 1976; Bloodstein, 1981, 1993, 1995; Silverman, 1996; Curlec, 1999, etc.) inspired other linguists to invent this new device. It is for this reason that we find psychoneurolinguists emphasizing applying some devices and programs that will, according to them, help stutterer overcome his/her stuttering. It is to be noted here that some people may not only have stuttering; rather, they might have more than one problem of speech disorders. 'Abdulhādī et al., (2002) for example are of the view that: "Students of difficult learning suffer from more than one speech and linguistic problem" ('Abdulhādi et al., 2002, P.223)

For the above mentioned reasons, some neurolinguists and SLP/Tsdecided to do some correlational studies with the aim to identify roles and effects among clients that might help them invent a better method for treatment. Attempting to identify the relationship between intelligence and speech disorders, Hamza (1979) for example, proves that it is "not the weakness of the brain, but the malfunction of language usage" (Melhem, 2002, P.189).

Another study on association between students' performance and speech disorders concludes that "the performance of the student who is suffering from stuttering is less than normal students in 6 months" (ibid. P.189).

Administering a pre-post-test program to identify the effect of repeated exposure to DAF during 3 months as an independent variable, Van Borsel et al., (2003) found that even when used as the only treatment approach outside therapeutic environment, DAF reduced stuttering. In order to administer a test, one should be able to clearly differentiate between stuttering and disfluency. To make it clear, if a stutterer and a person who is suffering from disfluency have been asked to articulate an utterance like "Sadeq's pen" for example, the former would pronounce it as "Sssssssssssssadeq's pen", while the latter would articulate it as "Sadeq.....Sadeq's pen". Commenting on such issue, Conture (1990) has rightly stated:"... who is and who is not stuttering is a relative, rather than an absolute decision." (Plante \& Besson, 2004, P.100)

Such distinction was based on approaches through which the idea of DAF was first released. In this regards, Packman \& Attanasio (2004) have rightly observed: "The idea of DAF started as theory emerged from Neilson's interest in Cybernatic approaches to speech that was later developed by Fairbanks in 1954.” (Packman \& Attanasio, 2004, P.78)

New studies focused on how techniques like DAF should be effectively used. For example, Freeman \& Friman (2004) investigated the use of simplified regulated breathing (SRB) with an adolescent stutter. The researchers concluded that SRB resulted in decreased stuttering for the participant, although differential effectiveness across conditions was noted. These results are discussed in terms of the generality of SRB across client population and client settings, as well as the value of addressing contextual variables when treating stuttering. In fact, all features of SRB were found in DAF; that is why, it was recommended by some psychoneurolinguists as a therapeutic means for children (Radford et al., 2005). Strictly, the 
misuse or malfunction of this device may lead to opposite results. As Bloodstein, (1995) has clearly stated: "DAF can improve fluency for stutterers, but impairs fluency for normal speakers." (Cutler, 2005, P.305)

Al-'ishāwi (2005) also discusses some of the consequences of misusing DAF, notably for male. According to him: " $25 \%$ of stuttering goes back to heritage factors and that the percentage of male stutterers is 4 times double than female" (Al- 'ishāwi, 2005, P.199)

Van Borsel et al., (2005) investigated Mackay's theory (1970) of language familiarity. The team attempted to answer the question: How does language familiarity influence stuttering under DAF in both male and females? Results did not reveal a clear gender difference. Not only correlational studies are involved, some others try experimental studies too. In their research " Stuttering as a monitoring deficit", Vasic \& Winen (2005) propose that "Stuttering stems from malfunctioning monitoring process" and after conducting an experimental study on 22 stutterers ( mild to severe) and 10 non-stuttering persons, they result that " Performing secondary, non-linguistic task, during speaking suppresses disfluency, particularly blocking, in persons who stutter." (Hastsuiker et al., 2005, P.226)

Morgan (2005) reports a potential client of a seven year-old deaf child with a familial history of stuttering (his hearing parents stutter). Commenting on this diagnosis, she states:

"The child scored above age-level on tests of British sign language comprehension, but during his spontaneous signing, he often repeated signs or parts of signs. However, he also has other nonlinguistic motor impairments and thus may suffer from a more general apraxia, rather than from a specific stuttering disorder." (ibid.P.305)

Another study by Russell et al., (2005) titled: "Magnitude estimation of disfluency by stutterers and non-stutterers" suggests that "for closely matched, naturally occurring segments of speech, listeners rate the speech of stutterers as more disfluent than that of non-stutterer. (ibid.P.248)

They finally came up with the crucial fact that DAF is incomparable especially after they observed its results on their clients. In his study titled: "Stuttering therapy in a framework of operant conditioning and programmed learning", Ryan mentioned some clients who were seeking an effective therapy. Such results encouraged some researchers to investigate the effects of DAF on groups of chanters (Van Wijngaarden \& Van Balken, 2007). FMRI studies proved that auditory feedback plays a pivotal role in natural speech production, notably in the control of pitch (Toyomura, 2007). Jones \& Striemer (2007) explored whether providing visual feedback in addition to DAF would ameliorate speech disruption. One of the results of the team was that although visual feedback did not reduce DAF effects on duration, no significant trend was observed for fewer speech disruptions when visual feedback was provided. Some Psychoneurolinguists stipulate four (4) conditions when considering use of DAF. Mainly, these are: factors inherent to the client such as gender, age, stuttering severity, disfluency pattern, origin of stuttering, and biological subtype; factors outside the client including delay time, intensity, manner of delivery, speech mode, and speech situation; possible side-effects like a reduction in speech rate, an increase of speaking fundamental 
frequency and vocal intensity, lengthening of vowels, and a possible effect on speech naturalness. Other factors are in a way or another related to cosmetics, finances, and the long-term effect (Van Borsel et al., 2007).

Investigating listeners' perception of the speech naturalness of people who stutter (PWS) speaking under DAF with particular attention for possible listener differences, Van Borsel \& Eeckhout(2008) found that for PWS, the slower a speaker's rate was, the less natural speech was judged to sound. Regarding the question: Who benefits more from DAF? Corey \& Cuddapah (2008) recommend that individual differences in attention control may help us understand gender difference in DAF effects and possibly in DS prevalence as well. Such recommendation was suggested due to the fact that DAF found to be the most disruptive to subsequent calls when the delay was 25 millisecond (ms.). It should be noted here that longer delays resulted in fewer errors (Osmanski \& Dooling, 2009). Sakai (2009) has undertaken a study to investigate cortical activations during speech production through the DAF effect. FMRI findings show higher activation in the right inferior frontal gyrus as well as in the right supplementary motor area and superior temporal gyrus. According to Sakai, such findings reconfirm most of the previous findings with some slightly different activation areas, and underscore the involvement of inferior frontal gyrus and superior temporal gyrus in disfluency.

Biotech Business Week editors (2009) published an article on a new device called "iPhone". According to the editors, the iPhone device was programmed at HCRI electronic company with a sophisticated voice monitoring system that evaluates and scores speech behaviors taught during stuttering therapy. When stutterers use the device during training in outside situations, such as shopping malls, restaurants or business settings, fluency measurements for each utterance are displayed on the iPhone screen. Having this datum immediately available to stuttering therapy program makes speech practice more effective and helps improve the speed with which fluency results are achieved. Explaining in brief the nature of this device, HCRI Founder and President Ronald L. Webster, Ph.D. state:" Our clients now have a dynamic, easy-to-use tool that can be used in virtually any setting to evaluate how well they are using newly learned fluency skills," Dr. Webster said. "In addition, the device provides training feedback and performance data that were previously available only with our clinic-based computers." (ibid. P. 1533)

Investigating the neural basis for the detection of and compensation for such a delay, and the effects of increases in the delay duration, results of Takaso et al., (2010) confirm the role for the posterior, sensorimotor "how" system in the production of speech under conditions of DAF. According to the team, all the peaks showed some influence of the amount of delay. Lincoln et al., (2010) investigated the impact on percentage of syllables stuttered of various durations of DAF. One of the suggestions made by the team is that studies that use standard DAF and frequency-altered feedback settings for all participants are likely to underestimate any altered auditory feedback effect. Some believed that the clue to overcome stuttering is by understanding the role of auditory information in organizing articulation (Mochida et al., 2010). Reporting the use of DAF in a 49-year-old man who started to stutter after traumatic brain injury, the results of Van Borsel et al., (2010) support the notion that neurogenic and 
developmental stuttering does not have a unifying pathology. Investigating Phonemic Content Hypothesis which suggests that speech disturbances arise from a disruptive rhythm that is produced by the delayed speech signal, the results of Kaspar \& Rübeling (2011) supports the hypothesis. According to Kaspar \& Rübeling, rhythm seems to be a significant criterion of speech monitoring, and hence a mismatch between spoken words and auditory feedback realized by DAF induces obvious speech problems on rhythmic level regardless of phonemic discrepancy at the same time. Such outcomes enhanced Yamamoto\& Kawabata (2011) to investigate the temporal tuning mechanism integrating vocal sensory and voice sounds under DAF with an adaptation technique. One of the findings of the study is that the lag adaptation induced a shift in simultaneity responses toward the adapted auditory delays. This indicates, according to Yamamoto\& Kawabata, that the temporal tuning mechanism in vocalization can be temporally recalibrated after prolonged exposure to delayed vocal sounds. The researchers also found that the temporal recalibration in vocalization can be affected by averaging delay times in the adaptation phase.

Designing three experiments to test whether perception and action are coordinated in a way that distinguishes sequencing from timing, Pfordresher \& Kulpa (2011) conclude to suggest that asynchronous altered auditory feedback perturbs the phase of an internal timekeeper, whereas alterations to feedback pitch over time degrade the internal representation of sequence structure. Reviewing studies related to the effects of DAF on speech fluency in individuals who stutter, Andrade (2011) concludes that the using DAF still does not have robust support for its applicability. Andrade justifies that as the methodological variability does not allow a consistent answer, or a trend about the effectiveness of the device, to be drawn. Pfordresher \& Dalla (2011) tested the hypothesis that disruption depends on the state of the movement trajectory at the onset of DAF. One of the findings of the research is that the effect of DAF on timing variability is directly influenced by the finger trajectory. According to Fujisaki (2012) delayed visual feedback is found to be effective on grooved pegboard test performance which supports the notion that two mechanisms (temporal as well as spatial displacements between motor and sensory feedback) operate under such techniques. What makes such techniques like DAF very important is that the signals it produces help stutterer to reduce his/ her stuttering frequency that is independent of the speaker's rate of speech (Hudock et al., 2011). Testing stuttering in gender, Swink (2012)'s outcomes confirm the notion that speech production suppresses auditory cortex responsiveness and males and females process altered auditory feedback differently while speaking.

\section{I.1 Aims of the Study}

After using DAF by many stutterers, some psychoneurolinguists observe that people may range from nearly full recovery to a vegetative state in very few severe clients. Other psychoneurolinguists hypothesized certain theories on the same issue. Taken together, the present study attempts at dis/proving such claims using this technique to treat a stutterer. More importantly, it attempts at addressing the following specific questions:

How can DAF help stutterers overcome their stuttering? To what extent can it help these people speak properly and normally in their everyday life? 
With which language aspect is DAF more helpful? Letters, Nouns, Verbs or sentences?

Do the outcomes of this study support theories and hypotheses of stuttering like phonemic content hypothesis, CRH, Johnson's theory, Brutten\& Shoemaker's hypothesis and Blood's or contradict them?

\subsection{Methodology}

$\mathrm{MO}$ is the client under question. He is 23 years old. He is a bilingual person (Arabic \&English). He had sustained stuttering in his early life due to some psychological pressures practiced against him from his family. MO experienced only limited improvement during stuttering therapy received in public communication and swallowing disorders centers and rehabilitation hospitals. After taking his consent to conduct the study, an intensive therapeutic treatment that lasted for 20 months has been given to him. The client had five sessions (a session per four months). He had to practice ten (10) phonemes, twenty (20) words (10 nouns and 10 verbs), and ten (10) sentences for four continuous hours every day. The focus was on the dynamics of conversational discourse. Having the collected data, the client's utterances were studied by the researchers before they were statistically analyzed by Statistical Program for Social Science (SPSS).

\section{Results}

\subsection{DAF's Role to Overcome Stuttering}

The first research question asked whether DAF is helpful or not in overcoming stuttering. In order to answer this question, it is necessary to have some background on the nature of stuttering. Some scholars of special education are of the view that "the varieties in linguistic disorders' phenomena are most often caused by several reasons.” (al-Rawsān, 1998, P.18)

Others believe that stuttering or stammering should be clearly identified. In her book "Services for those of Special Needs", Shaqueer (2005) considers stuttering as "A sort of speech and language's disorder just like tremors, aphasia, etc."(Shaqueer, 2005, P.277)

Heward (1992),Learner (1976,1993), and Hallahan (1994) differentiate between articulation disorders that include omission, substitution, addition, and distortions; voice disorders; speech disorders which includes stuttering, blocking, and cluttering; language disorders which includes language delay, aphasia, acquired aphasia, dysgraphia, dysnomia and apraxia and echolalia/agnosia. Based on such distinction, al-Batāyna et al., (2007) adds some reasons that might lead to speech disorders and mentions them as follows: "Organic reasons, Environmental reasons, Educational reasons, Internal Psychological reasons, and Functional reasons" (al-Batāyna et al., 2007, P.141)

For all what have been discussed earlier, the researchers diagnosed the type and nature of stuttering of this adult client, and recommended DAF for him as an ultimate solution after experiencing so many methods that had been uselessly ended. In fact, one of the major reasons behind recommending DAF for the case is that this electronic device is the most effective solution for overcoming stuttering. Additionally, it is not tough to be used. It consists of headset (headphones with microphone), power adapter, small ear set (optional), 
telephone cable (optional), and small screwdriver(optional). To talk at a normal speed, without speech therapy, the client adjusts the DELAY control of DAF to $55 \mathrm{~ms}$. and the PITCH control to a lower (deeper) pitch so that the device reduces his stuttering about $75 \%$. Of course, the client wants to reduce his stuttering $100 \%$; that is why he uses DAF with speech therapy that depends on various types of drills like talking with one second per syllable which is five times slower than normal speech. Another drill is stretching and emphasizing the vowel in each syllable. The client does not stretch consonants. He just reduces emphasizing them. In fact, he makes all consonants of equal length. In that sense, a word with four syllables should be four seconds long.

In order to achieve his dream i.e. to overcome his stuttering, the client has been asked to practice very slow speech with the "DELAY" control of his anti-stuttering device adjusted to $200 \mathrm{~ms}$., then practice very slow speech without using it following the advice of the researchers. Researchers also advised him to increase his talking speed gradually when he feels that he can talk at one second per syllable without stuttering by adjusting the "DELAY" control to $100 \mathrm{~ms}$. and practicing talking at one-half second per syllable, with and then without DAF. The client was also asked to increase his speed to one-quarter second per syllable whenever he feels that he can talk at one-half syllable per second without stuttering, by adjusting the "DELAY" control to $70 \mathrm{~ms}$. In that case, the client, according to the researchers, will notice that a slow normal speaking speed is a little slower than normal speech but sounds normal and clear.

The client was also advised to relax his lips, tongue, and jaw as he talks for better relaxed articulation. However, to relax his breathing, the client was strongly recommended to put one of his hands on his stomach. The researchers emphasized the fact that the client's hand should move out when he inhales, and in when he exhales. This is known as relaxed breathing and that is what the client was advised to practice. Of course, the client cannot say lots of words during this relaxed breathing. He can only say few words on each breath as he must slowly inhale without speaking, with equal time for inhalation and exhalation and must not speak when inhaling. The researchers made it clear to the client that he should exhale, say few words, stop talking, inhale slowly, then exhale and say few more words. They also advised the client not to take big breaths and hold the air in.

According to the researchers, the client has to relax his vocal folds by putting one of his hands on his throat, humming or saying "ah." to feel the vibration of his vocal folds and to talk slowly and stretch each vowel to feel that some consonants stop his vocal fold vibration. However, the researchers made it clear that these are the voiceless consonants that the client has to reduce until he feels his vocal folds vibrate continuously as he talks. Researchers realize that stutterers have difficulty switching their vocal folds on and off. Continuous phonation keeps their vocal folds vibrating. To that end, the researchers expect the client to feel that his vocal folds vibrate after he takes a breath, release a little air, and then slowly and gently tense his vocal folds. The researchers suggest that the client has to practice gently vibrating his vocal folds vs. tightly tensing his vocal folds and speak with his vocal folds gently vibrating. They also ask him to adjust the "PITCH" control in DAF to a lower (deeper) pitch, listen to his voice sounding deep or at a low pitch, feel his vocal folds, and try to relax 
his vocal folds to feel like that deep, relaxed voice he hears in the headphones. They also recommended the client to have some silent blocks, to push the button and the device makes a humming sound in his ears that sounds like his vocal folds are relaxed as this procedure relaxes his vocal folds and then he can talk easily.

The client has been asked to practice at least ninety minutes each day, and these hours are divided as follows: Half an hour for reading aloud, another half an hour for talking to family members, and half an hour for telephone calls. The researchers advised him to practice exaggerated speech, slow his speech, and his breathing and vocal folds very relaxed, and make his practice speech sound "extreme." Then when he talks to people, he has to use a little slower speech and a little relaxed breathing and relaxed vocal folds.

In addition to his practice through DAF, and for better treatment and encouraged results, the client was asked to record his speech and listen to himself, find where his relaxed, slow speech sounds are normal, practice in high stress situations, make telephone calls to businesses, join a public speech club in the KSA if any, volunteer for a job that requires talking to strangers such as a guide, a receptionist, information office, etc. Finally, researchers asked him not to be embarrassed about his stuttering and to tell people that he stutters. Moreover, researchers made it clear that he has to ask people what they think of his stuttering, make a joke about his stuttering, show people DAF, make a speech about stuttering to a group, talk to his classmates or teachers about his stuttering, etc. In addition, he has to join stuttering support group which can be found on internet by 'googling' as this will help him not to feel alone and his new stuttering friends will help him solve most problems related to stuttering.

\subsection{Language Aspects Overcome by DAF}

The research second question investigated which language aspect in particular is most likely overcome after using DAF. In order to answer this question, the client's utterances are tape recorded by the researchers who statistically analyzed them. These utterances as has been mentioned somewhere throughout this paper shed lights on some language aspects. These include: Alphabetical letters, nouns, verbs, and finally sentences. The items that have been investigated are the conclusion of the intensive program including all drills and exercises mentioned earlier. The performance of the client in the last two sessions was unbelievable. Language aspects were almost overcome by DAF. Descriptive analysis of the mean of all items divers between 4.58 as the minimum mean occurred in the word "dictation" and 7.72 as the maximum one occurred in letter "I" of the alphabet. Specifically, the following tables explain in details which language aspect is overcome due to the use of DAF. Consider:

Table 1. Statistical Analysis of alphabetical characters

\begin{tabular}{|l|l|l|l|l|l|}
\hline Items & Number & Minimum & Maximum & Mean & Std. of deviation \\
\hline A & 5 & 4.5 & 10 & 7.7 & 2.109502311 \\
\hline B & 5 & 1 & 10 & 6.9 & 3.507135583 \\
\hline C & 5 & 1 & 10 & 7.72 & 1.786616915 \\
\hline D & 5 & 4 & 10 & 7.18 & 2.135883892 \\
\hline E & 5 & 0 & 10 & 6.5 & 3.807886553 \\
\hline
\end{tabular}




\begin{tabular}{|l|l|l|l|l|l|}
\hline F & 5 & 0 & 10 & 6.46 & 3.798420724 \\
\hline G & 5 & 0 & 10 & 6.34 & 3.747399098 \\
\hline H & 5 & 0 & 10 & 6.32 & 3.743928418 \\
\hline I & 5 & 6.9 & 10 & 8.12 & 1.227599283 \\
\hline J & 5 & 5 & 10 & 7.48 & 1.803330253 \\
\hline
\end{tabular}

As can be clearly seen in the table, letters " $I$ ", " $C$ ", and " $J$ " registered the highest scores accordingly. On the other hand, letters " $B$ " and " $E$ " registered the lowest scores. In details, letter "I" scored the maximum mean (8.12) while letter " $E$ " scored the minimum mean (6.5). Considering all means, one can easily deduce that the client's pronunciation was highly improved and stuttering was widely overcome. The same thing applies to nouns that can be illustrated in the light of Table 2. Consider:

Table 2. Descriptive analysis of client's nouns utterances

\begin{tabular}{|l|l|l|l|l|l|}
\hline Items & Number & Minimum & Maximum & Mean & Std. of deviation \\
\hline Pen & 5 & 2.9 & 10 & 5.66 & 2.858845921 \\
\hline Party & 5 & 2.8 & 10 & 5.44 & 3.063168294 \\
\hline Book & 5 & 3 & 10 & 5.56 & 2.714406012 \\
\hline Bag & 5 & 0 & 10 & 5.78 & 4.005246559 \\
\hline Bank & 5 & 1 & 10 & 6.58 & 3.630702411 \\
\hline Dictation & 5 & 0 & 10 & 4.58 & 3.725855606 \\
\hline Language & 5 & 0 & 10 & 4.94 & 3.592770519 \\
\hline Construction & 5 & 1.9 & 10 & 4.78 & 3.1371962 \\
\hline Development & 5 & 3.5 & 9.8 & 5.64 & 2.502598649 \\
\hline Technology & 5 & 1.8 & 10 & 5.4 & 3.441656578 \\
\hline
\end{tabular}

Table 2 explains properly how the word "bank" scored the highest mean while the word "dictation" registered the lowest one. Looking at the minimum scores of the client at hand, it is identified that his performance was amazing, notably in the last two visits. In fact, the picture becomes clearer as we go through other language aspects. Table 3 summarizes the client's performance in verbs. Consider:

Table 3. The client's performance in uttering verbs

\begin{tabular}{|l|l|l|l|l|l|}
\hline Items & Number & Minimum & Maximum & Mean & Std. of deviation \\
\hline Study & 5 & 0 & 10 & 4.94 & 4.388393784 \\
\hline Play & 5 & 1 & 10 & 5.38 & 3.843435963 \\
\hline Swim & 5 & 0 & 10 & 4.8 & 4.549725266 \\
\hline Run & 5 & 1.9 & 10 & 7.22 & 3.133209217 \\
\hline Cut & 5 & 0 & 10 & 4.76 & 4.109501186 \\
\hline Teach & 5 & 1.5 & 10 & 4.76 & 3.655543735 \\
\hline Cry & 5 & 1.5 & 10 & 4.98 & 3.837577361 \\
\hline Blow & 5 & 1 & 10 & 5.86 & 4.277031681 \\
\hline Write & 5 & 1.9 & 10 & 5.74 & 3.212942577 \\
\hline Speak & 5 & 0 & 10 & 5.14 & 4.133763418 \\
\hline
\end{tabular}


Unlike his performance in alphabetical letters and nouns, the client's performance in verbs is the worst. Looking again at Table 3, one can easily realize the highest mean where the verb "run" registered 7.22 in comparison with the verb "swim" registered the lowest mean (4.8). The case is different when talking about sentences. Table 4 briefly discusses the statistical analysis of the client's performance in sentence's utterances. Consider:

Table 4. The client's utterances of sentences

\begin{tabular}{|l|l|l|l|l|l|}
\hline Items & Number & Minimum & Maximum & Mean & Std. of deviation \\
\hline $\begin{array}{l}\text { Simple present } \\
1\end{array}$ & 5 & 2 & 9.5 & 5.8 & 3.290136775 \\
\hline $\begin{array}{l}\text { Simple present } \\
2\end{array}$ & 5 & 0 & 9.9 & 6 & 4.153913817 \\
\hline $\begin{array}{l}\text { Simple present } \\
3\end{array}$ & 5 & 2 & 10 & 6.12 & 3.556262083 \\
\hline $\begin{array}{l}\text { Progressive } \\
\text { Present }\end{array}$ & 5 & 2 & 10 & 6.4 & 3.577708764 \\
\hline Simple Past & 5 & 1 & 9.9 & 5.78 & 4.061034351 \\
\hline $\begin{array}{l}\text { Perfect } \\
\text { Present A }\end{array}$ & 5 & 2 & 10 & 5.38 & 3.431034829 \\
\hline Future Far & 5 & 0 & 10 & 6.14 & 4.109501186 \\
\hline $\begin{array}{l}\text { Continuous } \\
\text { past }\end{array}$ & 5 & 1 & 9 & 5.7 & 3.327912258 \\
\hline $\begin{array}{l}\text { Perfect Present } \\
\text { B }\end{array}$ & 5 & 2 & 8 & 5.6 & 2.859195691 \\
\hline $\begin{array}{l}\text { Perfect Present } \\
\text { C }\end{array}$ & 5 & 0 & 7.8 & 4.96 & 3.685512176 \\
\hline
\end{tabular}

It might be true that client's performance as following in sentences was poor compared with his performance in alphabetical letters, but this does not mean neglecting his general performance which can be described as good in comparison to nouns and verbs. Taking into consideration the minimum, maximum and general mean of the utterances' results, we find that the client's speech has improved remarkably. The researchers also administered CHI-Square test based on one way sample to examine a hypothesis made bythemat the beginning that there is no impact of the time and number of visits on the improvement of the client's performance. Table 6 summarizes this relation. Consider:

Table 6. Chi-Square: Testing the researchers' hypothesis

\begin{tabular}{|l|l|l|l|}
\hline Tool & Value & $d f$ & Asypm. Sig.2-sided \\
\hline Pearson Chi-Square & $20.000 \mathrm{a}$ & 16 & .220 \\
\hline
\end{tabular}




\section{$\triangle$ Macrothink}

To make the results much more accurate and precise, the researchers did the following statistical equation:

$\mathrm{H} 0$ : There is no relation between dates of visits and scores in the client's performance.

H1: There is a relation between the two (dependent).

$\alpha=0.05$.

$\mathrm{Df}=16$.

P-Value $=20$.

Decision: $\mathrm{H} 0$ is not rejected since P-Value $>$ i.e. $20>0.05$. Consider:

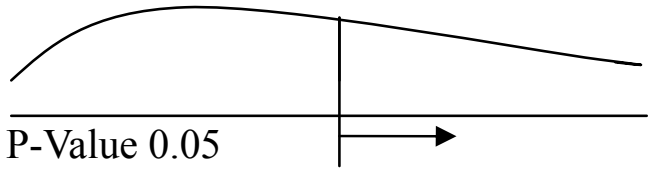

Reject

\section{Accept}

Deduction: There is no correlation between the date of visits and client's scores. In other words, $\mathrm{H} 0$ is accepted, which, in turns, leads to the fact that the development in the performance of the client is due to using DAF and that what the audio recordings prove. Nor must we forget to bear in mind that giving the client his freedom to express his ideas overtly, candidly, and also publicly directly after using DAF play an important role in his treatment of which sentence structure was the most difficult step. However, Mann \& Schoenheimer (1989), Vellutino (1987), Wiig \& Abele (1981) and Vodel (1977) are all agreed that the problem in these people of speech disorders is that they face problems in using language structures. Pearl $\&$ Bryant (1981) adds that as a result of the above mentioned reasons of the special needs specialists, "these people usually allow the other party whom they speak with to dominate conversation. Sometimes, they keep silent for long periods" (aL-Batāyna\&al-Jarrah, 2007, P.214)

Overall, one cannot forget the past or what is medically known as the history of the client. Looking backward, it is found that the client under the study was always a victim for all criticism of the society members in general and the family members in particular. According to Wingate (1962), Johnson'e theory of stuttering involves the following three assumptions:

1. Most normal young children speak with a considerable amount of repetition and other breaks in influence.

2. Adult differ in their standard of fluency, and some react to the hesitant speech of children with unusual intolerance.

3. Children who are penalized for normal non fluencies are likely to develop stuttering.

However, some psychoneurolinguists believe that stuttering results from faulty breathing. Sokina (1947) has made observations of the movement of diagram of stutterers, making use of the anemographic method and the radio kymograph. When sufficiently accurate data on the movements of the diagram had been obtained, it was revealed, according to Sokina, that "in evolutional or functional stuttering, rest breathing is completely normal and rhythmic, 


\section{Macrothink \\ International Journal of English Language Education \\ ISSN 2325-0887 \\ 2013, Vol. 1, No. 2, Special Issue}

changing sharply during speech" (Sokina, 1947, P.166)

Commenting on such findings, Zinkin (1968) adds: "The lack of information about the function of speech organs is reflected in, yet another concept which is central for the problem of stuttering" (Zinkin, 1968,P.112)

Philips (1975) list 15 agreed-on-facts about stuttering and mentioned them as follows:

1. The average stutterer stutters on only about $10 \%$ of his utterances which means that $90 \%$ of the time he is fluent.

2. Most stuttering last only one or two seconds- or less.

3. No two stutterers perform their stuttering in exactly the same way.

4. Stuttering begins, on the average, at about the age of 3 years -some earlier, some later.

5. A considerable number of individuals are reported to have stuttered during some period in their lives and to have "outgrown" the difficulty without treatment.

6. Practically all stutterers are originally diagnosed by laymen, not a speech clinician.

7. Practically all children so diagnosed have spoken for from six months to several years without being regarded as defective in speech or as being abnormal.

8. So-called stuttering children are like non-stuttering children with respect to handedness and handedness development.

9. Stuttering has been eliminated in a number of clients by means involving no recognized changes in the organic condition of the stutterer.

10. There are conditions under which the stutterer is fluent. These may be divided into two groups of situations: (a) Conditions under which the stutterer hears himself abnormally as in choral reading, singing, or with interfering noise and /9b) those in which he places no premium on fluency because he feels adequate as a speaker, as when talking to pets, small children, or himself.

11. Stuttering more occurs on the words that are nouns, verbs, adjectives and adverbs; words that begin sentences; words that are longer than average; and words that begin with consonants.

12. Studies have found no differences between young adult stutterers and non-stutterers in ability to perform rapid or rhythmical movement of lips, tongue, jaw, and breathing musculature.

13. Boys more than girls stutter.

14. Stuttering behavior appears to run in families. (P.84)

Although the results have shown that the client at hand is well improved, the researchers expect him to stutter every now and then (even though he has taken intensive drillsusing DAF). Supporting this expectation, Palmer \& Yantis (1990) state"....Obviously, stuttering is a 
complex disorder and it is far from solved. Yet, there are many fine speech pathologists successfully assisting persons who stutter to communicate better."(Palmer \& Yantis, 1990, P.126)

The question now is: Will people notice if the client stutters again? In other words, will they be able to distinguish whether he used to be stutterer or not? The researchers believe that the answers to such questions will probably be "may be". Of course, this is not because stuttering can be recognized, but because there is no clear cut between stuttering and normal disfluency. The dividing line between the two, according to Perkins (1977) "...is ambiguous" (Perkins, 1977, P.296)

Bloodstein (1960a, 1960b) describes four general phases of stuttering development and mentioned them as follows: The stuttering is episodic, has become more chronic, many vary with specific situations and that stutter goes through very fearful anticipation of stuttering, fears words, sounds, and situation, and this phase is usually seen in late adolescence and adulthood. Likewise, Riper (1954) has suggested a three-stage developmental process: "Primary stuttering, transition, and secondary stuttering." (Shames \& Wiig, 1982, P.197)

Some changes in chest circumference and lung capacity in stutterers may occur as a result of treatment. Consider: Circumference of the chest of clients in drawing a deep breath:

Before the cure: $77,82,91$, and 94

After the cure: $82, \quad 86,95,4,99,5$ Centimeter

Then more: $\quad 5,4, \quad 4,45,5$

Inhaled air from deep drawing of breath:

Before the cure: $1672, \quad 1946,2154, \quad$ and 2240

After the cure: $2248, \quad 2820,2854, \quad 3376 \quad$ Cubic-centimeter.

Then more: $\quad 576, \quad 874, \quad 700, \quad 1136$

Source: Gerdts (1883, P.48)

As a matter of fact, there are many factors that enabled the client at hand overcome his stuttering. These factors include the client's willing and his desire to compensate all those years he spent looking for a method of treatment, but in vain. Nor must we forget the client's painful childhood which was full of insulting situations, punishment and offensive words. Such banal things along with other critical situations participated in a way or another in increasing his suffering from stuttering. Importantly, these factors finally became motives that lead him not only to overcome stuttering but also to improve his pronunciation and speech.

\section{$2.3 \mathrm{In} /$ Validating Theories and Hypotheses}

Having the collected utterances, the researchers listened to them and analyzed them linguistically before undertaking the statistical treatment. The team noticed that there was an obstruction between the real production of the client under investigation, notably with the 


\section{Ml Macrothink}

International Journal of English Language Education

ISSN 2325-0887

2013, Vol. 1, No. 2, Special Issue

alphabet and the delayed feedback signal. With the passage of utterances, this interference was also observed in many sounds. Such results, according to the researchers, confirm the arguments presented by the Phonemic content hypothesis. They also support the findings of Kaspar \& Rübeling (2011). The client's utterances show that he knows when his stuttering starts; that is why, he attempted to rush to avoid such stoppage. Strictly, the intensive training helped him to overcome such pauses. Again, having this predisposition was the cause of overcoming stuttering in his speech and this agrees with CRH. Looked at it psychologically, the client's stuttering was due to familial pressure. The client's childhood history was full of punishment and insult when he was talking publically. Sometimes he received offensive words by his parents and other family members. Such wrong behavior, according to the researchers, is the reason behind the client's stuttering. This result supports Johnson's theory of stuttering stating that children who are penalized for normal non fluencies are likely to develop stuttering and that adults differ in their standards of fluency. The findings of this study contradict Brutten \& Shoemaker (1967)'s hypothesis that stutterers have generally high levels of emotional reactivity because the client at hand is sociable with people and talkative with any foreign person.

\section{Discussion\& Recommendations}

\subsection{Discussion}

The client at hand was suffering from stuttering. In order to overcome his stuttering and reduce his speech, he has been asked to use DAF. After continuous practice due to the intensive program of drills and exercises, he was able to speak proper letters, nouns, verbs and even sentences. In comparison with nouns and verbs, alphabetical characters and sentences registered the highest scores. The following diagram concludes all results of language aspects' output. Consider

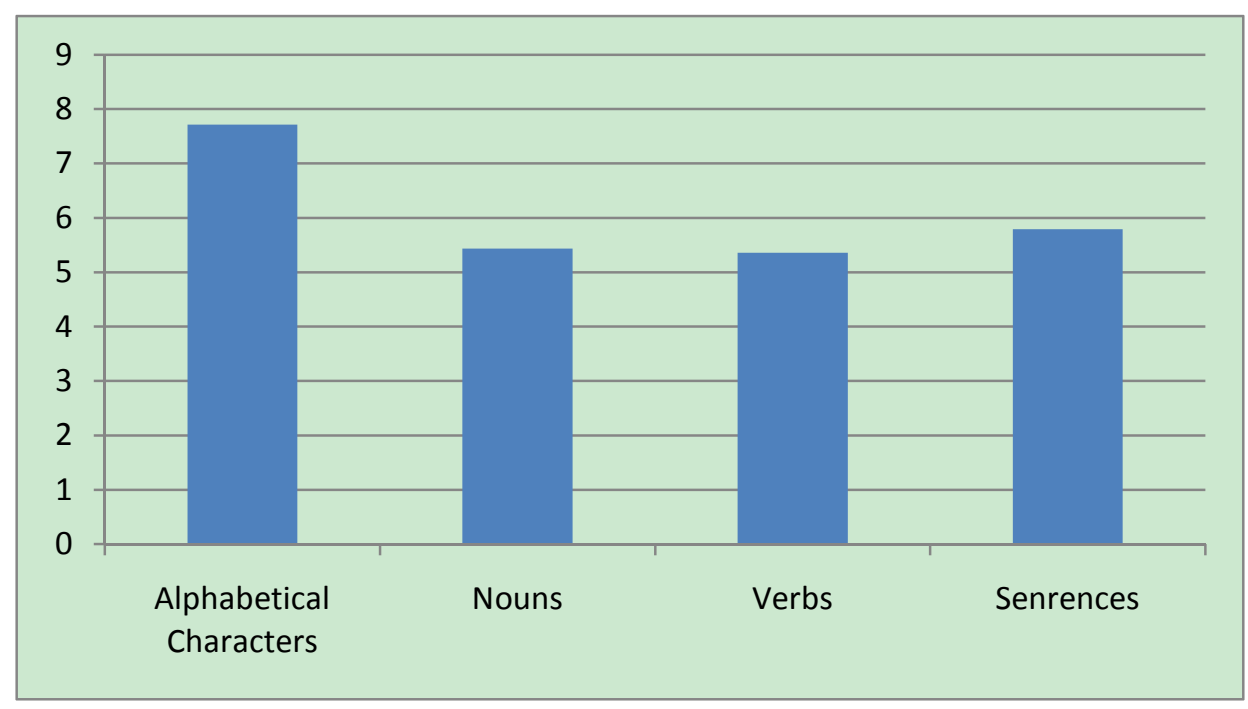

Figure 1. Results of language aspects after using DAF: Comparison 
As can be obviously seen in Figure 1, alphabetical characters occupied the first rank followed by sentences, nouns and verbs. The mean of all means indicates that final scores of all language aspects under the question were as follows: alphabetical characters $=7.72$, nouns $=$ 5.436 , verbs $=5.358$ and sentences $=5.788$. Such findings agree with different theories and hypotheses. These include: Phonemic content hypothesis, Covert Repair Hypothesis ( $\mathrm{CRH})$, and Johnson's theory of stuttering. They also confirm the outcomes of Kaspar \& Rübeling (2011). However, the findings of the present study are contradictory to the results of Brutten \& Shoemaker (1967)'s hypothesis that stutterers have generally high levels of emotional reactivity. The researchers made it clear in the previous chapter that the client at hand was an active and sociable person with all community members. Therefore, he does not have high level of emotional reactivity. Conversely, he proved himself to have low level of emotional reactivity.

Psychoneurolinguistically speaking, there is no connection between dichotic listening and stuttering In their research titled: " The Performance of Stutterers on Dichotic Listening Tasks Thought to Reflect Cerebral Dominance" published by Journal of Speech and hearing research, Curry (1967) support this fact by clarifying that"...Differences in dichotic listening per se are not related to stuttering since dichotic listening is rarely done in real life situations." (Curry, 1967, P.529)

Of course stutterers used to suffer from daily life activities every now and then. This suffering is reflected in their everyday life such as their school performance. Bloodstein (1995) and Conture (1996) realized that Stutterers, on the whole, perform poorly in educational adjustment than normal speakers (Owen et al., 2003). Moreover, the effects of stuttering purchase them to their social interactions. Conture, (1990) indicates that "Clinical observations suggest that successfully treated individuals, particularly adults, experience an improvement in their social interactions, but the nature and significance of these changes in social behavior are not well documented." (ibid. P.255)

One cannot deny of course the effects of stuttering on work especially for those adults who want to avoid stuttering in front of their colleagues, particularly if they are of the opposite sex. Moreover, managers look at stuttering as a disorder that decreases employability and opportunities of promotions if not cancels them. Stutterers for them is a handicapped person and normally (especially private sectors) they do not want to take a risk to hire him since hundreds if not thousands are on the waiting list, ready to take this job, and do well in it. "Despite of this view", added Craig \& Clavert (1991) "When an employee who stutters seeks treatment, there is an attendant improvement in the employer's perception of the employee." (P.279-84)

\subsection{Recommendations}

In fact, as have been discussed earlier, many neuropsychologists and(SLP/Ts) recommend DAF as a crucial solution for stutterers that will definitely help them ameliorate their stuttering (Soderberg, 1969; Wingate,1970, Van Riper, 1970; 1976,1978;Bloodstein, 1981; Byrne, 1983). 


\section{Mll Macrothink}

International Journal of English Language Education

2013, Vol. 1, No. 2, Special Issue

In his research titled: "A Prospective on Approaches to Stuttering Therapy”, Win (1979) suggests that stutterers have to "attend to the newness in order, for example, to talk in the presence of DAF, or to talk with an exceedingly slow rate" (Gregory, 1979, P.249)

Supporting the recommendations of specialists, SLPs, the researcher recommends that the program has to be used under a supervision of a specialist, as misusing it by one's own (without instructions) may lead, according to Preus (1977) to "some effects which are by no means equivocal in all stutterers." (Preus, 1977, P.68)

The researcher also recommends those who stutter to practice with DAF all the day and go apply what they have practiced among society members to encourage themselves to overcome their stuttering. As can been from the client in question, two years of continuous exercises consolidated relationships between DAF and stutterer performance which means that DAF has been documented to improve fluency in them. Finally, it is hoped that this study might be of use to Rehabilitation Centers specialized in Articulation in those areas that relate to Rehabilitation of Dyslexics since most clients of stuttering result from psychological problems that go back to the early past of the client. Of course, other similar institutions can benefit from the findings of this investigation.

\section{Acknowledgment}

I am very grateful to Prof. Kebbe who inspired me with his brilliant ideas.

\section{References}

'Abdul-Hādī, N., Nasrullāh, '., \& Shiqīr, S. (2000). Buța' al-T'allum Wa Șu'ūbātuh. Ṭ1 . 'Ammān: Dār Wā'il Lil-Nashr.

Abbs, J., \& Gracco, V. (1984). Control of Complex Motor Gestures:Orofacial Muscle Responses to load Pertubations of lip during speech. Journal of Neurophysiology, 705-723.

Abu-Ghazālah, H., \& Jaradāt, '. (1986). Damj al-Mu'āqīn Sam'iyan Fl al-Madāris al-'Ādiyah. ‘Ammān: al-Ittiḥād al-'Arabī Lil-Hayāt al-'Āmilah Fī Ri ‘āyat al-Ṣumm.

al-'Ashmāwī, H. (2005). Șu'ūbāt al-Lughah Wa Iḍtirābāt al-Kalām: al-Kashf al-Mubakkir Lișu'ūbāt al-T‘allum Lil-Ațāl Mā Qabl al-Madrasah. Ṭ1 . Dimishq: Dār al-Shajarah Lil-Nashr Wa al-Tawzīa . al-Bațaynah, '., al-Rashdān, M., al-Sabāylah, '., \& al-Khațāțbah, '. (2007). Șu'ūbāt al-T'allum: al-Nazariyah Wa al-Mumārasah. T1. 'Ammān: Dār al-Masīrah Lil-Nashr Wa al-Tawzī Wa al-Ṭibā'ah .

al-Rawsān, F. (1998). Sikulūjïyat al-Ațāal Ghayr al-'Ādiyīn: Muqaddimah Fi al-Tarbiyah al-Khāșșah . 'Ammān: Dār al-Fikr Lil-Ṭibā'ah Wa al-Nashr Wa al-Tawzī' .

al-Rawsān, F. (2000). Muqaddimah FI al-lḍtirābāt al-Lughawiyah. T11 . ar-Riyāḍ: Dār al-Zahrā' Lil-Nashr Wa al-Tawzì . 


\section{Macrothink \\ International Journal of English Language Education ISSN 2325-0887 \\ 2013, Vol. 1, No. 2, Special Issue}

al-Zarrād, F. (1990). al-Lughah Wa Iḍtirābāt al-Nuṭq Wa al-Kalām . Ar-Riyāọ: Dār al-Marrīkh Lil-Nashr .

Andrade, C., \& Juste, F. (2011). [Systematic review of delayed auditory feedback effectiveness for stuttering reduction]. Jornal Da Sociedade Brasileira De Fonoaudiologia, 23(2), 187-191. Jornal Da Sociedade Brasileira De Fonoaudiologia, 187-191.

Andrews, C., Craig, A., Feyer, A., Haddinott, S., Neilson, M., \& Howle, P. (1983). Stuttering: A Review of Research Findings and Theories Circa 1982. Journal of Speech, 2-9.

Bloodstein, O. (1960). The Development of Stuttering: II. Developmental Phases. Journal of Speech and Hearing Disorders, 366-376.

Bloodstein, O. (1960). The Development of Stuttering: I.Changes in Nine Basic Features. Journal of Speech and Hearing Disorders, 219-237.

Bloodstein, O. (1981). A Handbook on Stuttering . Chicago: National Easter Seal Society.

Bloodstein, O. (1993). The Search for a Cause and Cure. Bosten: Allyn and Bacon.

Bloodstein, O. (1995). A Handbook on stuttering (5th ed.). Chicago: National Easter Seal Society.

Bossom, J. (1974). Movement without proprioception. Brian Research, 285-296.

Brutten, E., \& Shoemaker, D. (1967). Modification of Stuttering. Englewood Cliffs: Prentice Hall.

Byrne, R. (1983). Let's Talk about Stammering. London: George Allen\&Unwin (Publishers) Ltd.

Chase, R. (1958). Effect of Delayed Auditory Feedback on the Repitition of Speech Sounds . J. Speech Hearing Dis., 583-90.

Conture, E. (1990). Childhood Stuttering: What Is It and Who Does It?. ASHA Report Series, 2-14.

Corey, D., \& Cuddapah, V. (2008). Delayed auditory feedback effects during reading and conversation tasks: Gender differences in fluent adults. Journal Of Fluency Disorders, 291-305. http://dx.doi.org/10.1016/j.jfludis.2008.12.001.

Craig, A., \& Clavert, P. (1991). Following Up on Treated Stutterers: Studies of Perception of Fluency and Job Status. Journal of Speech and Hearing Research, 279-284.

Curlee, R. (1999). Stuttering and Related Disorders of Fluency,2nd ed. New York: Thieme.

Curry, F. (1967). A Comparison of Left-Handed and Right-Handed Subjects on Verbal and Non-Verbal Dichotic Listening Tasks. Cortex, 343-352.

Cutler, A. (2005). Twenty-First Century Psycholinguistics:Four Cornerstones. New Jesrsy: Lawrence Erlbaum Associates. 
Dalton, P., \& Hardcastle, W. (1977). Disorders of Fluency and their Effects on Communication. London: Edward Arnold (Publishers) Ltd.

Eisenson, J. (1975). Stuttering: A Second Symposium. New York: Harper\& Row, Publishers.

Fairbanks, G. (1954). Systematic Research in Experimental Phonetics:1. A Theory of the Speech System as A Servosystem. Journal of Speech and Hearing Disorders, 133-139.

Fairbanks, G. (1955). Selective Vocal Effects of Delayed Auditory Feedback. J. Speech Hearing Dis, 333-46.

Fairbanks, G., \& Guttman, N. (1958). Effects of delayed auditory feedback on articulation. Journal of Speech and Hearing Research, 12-22.

Fentress, J. (1979). Development of Grooming in Mice without Ampulated Forelimbs. Science, 704-705.

Folkins, J., \& Abbs, J. (1975). Lip and Jaw Motor Control During Speech: Responses to Resistive Loading of the Jaw. Journal of Speech and Hearing Research, 207-220.

Freeman, K., \& Friman, P. (2004). Using simplified regulated breathing with an adolescent stutterer: Aplication of effective intervention in a residual context. Article. Behavior Modification. Beverly Hills, 247.

Fujisaki, W. (2012). Effects of delayed visual feedback on grooved pegboard test performance. Frontiers In Psychology, 361.

Gammon, S., Smith, P., Daniloff, R., \& Kim, C. (1971). Articulation and Stress, Juncture Production Under Oral Anaesthetization and Mosking. JSHR, 271-82.

Goldiamond, I. (1965). Stuttering and Fluency as Manipulable Operant Response Classes. In L.Krasner and L.P. Ulman,eds., Rsearch in Behavior Modification. New York: Holt, Rinhart\& Winston.

Gracco, V. (1984). Time Varying Sensorimotor Processes of the Perioral System During Speech. Journal of University of Wisconsin.Madison., 2-13.

Gracco, V., \& Abbs, J. (1985). Dynamic Control of the Perioral System During Speech:Kinematic Analyses of Autogenic and Non Autogenic Sensimotor Processes. Journal of Neurophysiology, 418-432.

Gracco, V., \& Abbs, J. (1987). Programming and Execution Processes of Speech Movement Control: Potential Neural Correlates. In E.Keller \&M.Gopnik(Eds.), Motor and Sensory Processes in Language. New Jersey: Hillsdale,Lawrence Erlbaum Associates, Inc.

Gregory, H. (1979). Controversies about Stuttering Therapy. Batimore: University Park Press.

Hallahan, D., \& Kauffman, J. (1994). Exceptional Children: Introduction to Special Education. New Jersey: Prentice-Hall, Inc.England Cliffs. 


\section{Mll Macrothink}

International Journal of English Language Education

ISSN 2325-0887

2013, Vol. 1, No. 2, Special Issue

Hardcastle, W. (1975). Some Aspects of Speech Production Under Controlled Conditions of Oral Anaesthesia and Auditory Masking. J.Phonetics, 214.

Henry, F., \& Rogers, D. (1960). Increased Response Latency for Complicated Movements and a "Memory Drum". Theory of Neuromotor Reaction. Research Quarterly, 448-58.

Heward, W. (1992). Exceptional Children: An Introductory Survey of Special Education(4th ed.). New York: Merillanim Print of Macmillan Publishing Company.

Horii, Y., House, A., \& Ringel, R. (1973). A Coustic Characterstics of Speech Produced without Oral Sensation. JSHR, 67-77.

Hudock, D., Dayalu, V., Saltuklaroglu, T., Stuart, A., Zhang, J., \& Kalinowski, J. (2011). Stuttering inhibition via visual feedback at normal and fast speech rates. International Journal Of Language \& Communication Disorders, 169-178. http://dx.doi.org/10.3109/13682822.2010.490574.

James, W. (1890). The Principles of Psychology: Vol.1. London: MacMillan.

Johnson, W. (1942). Study of the Onset and Development of Stuttering. Journal of Speech Disorders, 251-257.

Johnson, W. (1961a). Measurements of Oral Reading and Speaking Rate and Disfluency of Adult Male and Female Stutterers and Non Stutterers. J.Speech Hearing Dis., Monogr.Suppl, $1-20$.

Jones, J., \& Striemer, D. (2007). Speech disruption during delayed auditory feedback with simultaneous visual feedback. Journal of The Acoustical Society Of America, 3-14.EL135-EL141. http://dx.doi.org/10.1121/1.2772402.

Jones, M., Onslow, M., Harrison, E., \& Packman, A. (2000). Treating stuttering in young children: Predicting treatment time in the lidcombe program. Article. Journal of Speech, Language, and Hearing Research, 440.

Kaspar, K., \& Rübeling, H. (2011). Rhythmic Versus Phonemic Interference in Delayed Auditory Feedback. Journal Of Speech, Language \& Hearing Research, 932-943. http://dx.doi.org/10.1044/1092-4388(2010/10-0109).

Keele, S. (1982). Learning and Control of Coordinated Motor Patterns: The Programming Perspective. In J.A.S.Kelso (Ed.),Human Motor Behavior:An Introduction (PP.161-186) . Hillsdale. New Jersy: Lawrence Erlbaum Associates.

Kelso, J., Tuller, B., Bateson, E., \& Fowler, C. (1984). Functionally Specific Articulatory Cooperation Following Jaw Pertubations During Speech: Evidence for Coordinative Structures. Journal of Experimental Psychology: Human Perception and Performance, 812-822.

Kirk, S. (1993). Educating Exceptional Children. Boston: Houghton Mifflin. 
Lane, J., \& Tranel, B. (1971). The Lombard Sign and the Role of Hearing in Speech. Journal of Speech and Hearing Research, 677-709.

Lashley, K. (1917). The Accuracy of Movement in the Absence of Excitation from the Moving Organ. American Journal of Physiology, 169-194.

Lashley, K. (1951). The problem of Serial Order in Behavior. In L.A.Jeffress(Ed.), Cerebral Mechanisms in Behavior:The Hixon Symposium (PP.112-146). New York: Wiley .

Lee, B. (1950a). Effects of Side-tone Delay. J. A Coust.Soc.Amer, 639-640.

Lee, B. (1950b). Effects of Delayed Speech Feedback. J.A Coust.Soc.Amer, 824-826.

Lincoln, M., Packman, A., Onslow, M., \& Jones, M. (2010). An Experimental Investigation of the Effect of Altered Auditory Feedback on the Conversational Speech of Adults Who Stutter. Journal Of Speech, Language \& Hearing Research, 1122-1131. http://dx.doi.org/10.1044/1092-4388(2009/07-0266).

Mann, V., Cowin, E., \& Schoenheimer, J. (1989). Phonological Processing Language Comprehension \&Reading Ability. Journal of Learning Disabilities, 6-89.

Melḥim, S. (2002). Șu'ūbāt al-T'allum. Ṭl . 'Ammān: Dār al-Masīrah Lil-Nashr Wa al-Tawzī'a Wa al-Tíibā'ah .

Mochida, T., Gomi, H., \& Kashino, M. (2010). Rapid change in articulatory lip movement induced by preceding auditory feedback during production of bilabial plosives. Plos One, 13866.

Mochida, T., Gomi, H., \& Kashino, M. (2010). Rapid Change in Articulatory Lip Movement Induced by Preceding Auditory Feedback during Production of Bilabial Plosives. Plos ONE, 1-10. doi:10.1371/journal.pone.0013866.

Neilson, M., \& Neilson, P. (1985). Speech Motor Control and Stuttering. In D.G. Russell\&B. Abernathy(Eds.), Motor Memory and Control. Dunedin,Human Performance Associates, 68-80.

Osmanski, M., \& Dooling, R. (2009). The effect of altered auditory feedback on control of vocal production in budgerigars (Melopsittacus undulatus). The Journal Of The Acoustical Society Of America, 911-919.

Owens, R., \& David Metz, A. H. (2003). Introduction to Communication Disorders: A Life Span Perspective (2nd ed.). London: Pearson Education, Inc.

Palmer, J., \& Yantis, P. (1990). Survey of Communication Disorders. New York : Williams\& Wilkins.

Pearl, R., Donahue, M., \& Bryant, T. (1981). Learning Disabled and Normal Children's Responses to Non-Explicit Re-Quests for Clarification. Perceptual and Motor Skills, 919-925. 


\section{I Macrothink}

International Journal of English Language Education ISSN 2325-0887 2013, Vol. 1, No. 2, Special Issue

Perkins, W. (1977). Speech Pathology: An Applied Behavioral Science.(2nd ed.). S. Louis : The C.V. Mosby Company.

Pfordresher, P., \& Dalla, B. (2011). Delayed Auditory Feedback and Movement. Journal Of Experimental Psychology: Human Perception And Performance, 566-579.

Pfordresher, P., \& Kulpa, J. (2011). The Dynamics of Disruption from Altered Auditory Feedback: Further Evidence for a Dissociation of Sequencing and Timing. Journal Of Experimental Psychology: Human Perception And Performance, 949-967.

Philips, P. (1975). Speech and Hearing Problems in the Classroom. Lincoln: Cliffs Notes, Inc.

Plante, E., \& Besson, P. (2004). Communication and Communication Disorders: A Clinical Introduction. London: Pearson Education, Inc.

Polit, A., \& Bizzi, E. (1979). Charactersitics of Motor Programs Underlying Arm Movements in Monkeys. Journal of Neurophysiology, 183-194.

Preus, A. (1977). Stammering og Lopsk Tale. Oslo: Universitetsforlaget.

Radford, N., Tanguma, J., Gonzalez, M., Nericcio, M., \& Newman, D. (2005). A case study of mediated learning, delayed auditory feedback, and motor repatterning to reduce stuttering. Perceptual And Motor Skills, 63-71.

Rieberl, R. (1976). The Neurology of Language. New York: Plenum Press.

Ringel, R., \& Steer, M. (1963). Some Effects of Tactile and Auditory Alteractions on Speech Output. JSHR , 369-378.

Riper, R. (1976). The Neuropsychology of Language. New York: Plenum.

Riper, V. (1954). Speech Correlation: Principles and Methods(3rd ed.) Englewood Cliffs. New Jersy : Prentice-Hall.

Rothwell, J., Traub, M., Day, B., Obseso, J., Thomas, P., \& Marden, C. (1982). Manual Motor Performance in A Deafferented Man. Brain, 515-542.

Sakai, N., Masuda, S., Shimotomai, T., \& Mori, K. (2009). Brain activation in adults who stutter under delayed auditory feedback: an fMRI study. International Journal Of Speech-Language Pathology, 2-11.

Sanes, J., \& Evarts, E. (1983). Regulatory Role of Prioceptive Input in Motor Control of Phasic or Maintained Voluntary Contractions in Man. In J.Desmedt(Ed.).Advances in, 3-14.

Scott, C., \& Ringel, R. (1971). Articulation without Oral Sensory Control. JSHR , 804-18.

Shaiman, S., Abbs, J., \& Gracco, V. (1985). Sensoriomotor Contributations to Oral-Laryngeal Coordination for Speech. Society for Neuroscience Abstracts, 15,76.

Shames, G., \& Wiig, E. (1982). Human Communication Disorders: An Introduction. Ohio: Charles,E. Merril Publishing. 
Sheehan, J. (1970). Stuttering: Research and Therapy. New York: Harper\&Row.

Sheelan, J. (1970a). Stuttering: Research and Therapy. New York: Harper\& Row.

Silverman, F. (1996). Stuttering and Other Fluency Disorders. Boston: Allyn and Bacon.

Skinner, B. (1953). Science and Human Behavior. New York: Macmillan.

Soderberg, G. (1969). Delayed Auditory Feedback and the Speech of Stutterers. A Review of Studies. J.Speech Hearing Dis, 20-29.

Sokina, A. (1947). Nekotorye Osobennosti Rasstrojstva Dyxanija Pri Kommocionno-Kontuzionnyx $\quad$ Logopatijax $(=\quad$ Trudy Lening Radskogo Naucno-Issledovatel'Skogo in-ta po boleznjam uxa,nosa,Gorlaireci,V.V111). Leningrad,Medgiz, 5-8.

Solomon, R., \& Brush, E. (1956). Experimentally Derived Conceptions of Anxiety and Aversion.In M.R. Jones,ed., Nebraska Symposium on Motivation. Lincoln: University of Nebraska Press.

Stromsta, C. (1957). A Methodology Related to the Determination of the Phase Angle of Bone-Conducted Speech Sound Energy of Stutterers and Non stutterers. Speech Monogr, $147-48$.

Stuart, A., \& Kalinowski, J. (1996). Fluent speech, fast articulatory rate, and delayed auditory feedback: creating a crisis for a scientific revolution? Perceptual And Motor Skills, 211-218.

Takaso, H., Eisner, F., Wise, R., \& Scott, S. (2010). The effect of delayed auditory feedback on activity in the temporal lobe while speaking: a positron emission tomography study. Journal Of Speech, Language \& Hearing Research, 226-236. http://dx.doi.org/10.1044/1092-4388(2009/09-0009).

Taub, E., \& Berman, A. (1968). Movement and Learning in the Absence of Sensory Feedback. In S.J.Freedman (Ed.). The Neurophysiology of Spartially Oriented Behavior. Illnois: Dorsey Press.

Tellis, G. (1996). Efficacy of the computer-aided fluency establishment trainer in the treatment of stuttering. Journal California State University, Fresno, 136 .

Toyomura, A., Koyama, S., Miyamaoto, T., Terao, A., Omori, T., Murohashi, H., \& Kuriki, S. (2007). Neural correlates of auditory feedback control in human. Neuroscience, 499-503.

Van Borsel, J., \& Eeckhout, H. (2008). The Speech Naturalness of People Who Stutter Speaking under Delayed Auditory Feedback as Perceived by Different Groups of Listeners. Journal Of Fluency Disorders, 241-251.

Van Borsel, J., Drummond, D., \& Pereira, M. d.-B. (2010). Delayed auditory feedback and acquired neurogenic stuttering. Journal Of Neurolinguistics, 479-487. http://dx.doi.org/10.1016/j.jneuroling.2009.01.001. 
Van Borsel.J.\& Reunes, G. (2003). Delayed auditory feedback in the treatment of stuttering: clients as consumers. International Journal Of Language \& Communication Disorders, 119-129.

Van Borsel, J., Sierens, S., \& Pereira, M. (2007). [Using delayed auditory feedback in the treatment of stuttering: evidence to consider]. Pró-Fono: Revista De Atualização Científica, 323-332. http://dx.doi.org/10.1121/1.2740054.

Van Borsel, J., Sunaert, R., \& Engelen, S. (2005). Speech Disruption under Delayed Auditory Feedback in Multilingual Speakers. Journal Of Fluency Disorders, 201-217.

Van Riper, C. (1970). The Use of DAF in Stuttering Therapy. Brit.J.Dis.Communic, 40-45.

Van Riper, C. (1971). The Nature of Stuttering. New Jersy: Englewood Cliffs N,J.Prentice-Hall.

Van Riper, C. (1973). The Treatment of Stuttering. New Jersy: Englewood Cliffs,N.Prentice-Hall.

Van Wijngaarden, S., \& Van-Balken, J. (2007). Theoretical feasibility of suppressing offensive sports chants by means of delayed feedback of sound. Journal Of The Acoustical Society Of America, 436-445. http://dx.doi.org/10.1121/1.2740054.

Vellutino, F. (1987). Dyslexia. Scientific American, 34-41.

Wall, M. (1988). Disfluency in The Child. In N.J.Lass,L.V.McReynolds,J.L.Northern, \& D.E. Yoder (Eds.), Handbook of Speech-Language Pathology and Audiology. Philadelphia: B.C.Decker.

Wiig, E., Semel, E., \& Abele, E. (1981). Perception of Ambiguous Sentences by Learning Disabled Twelve Year Olds. Learning Disability Quarterly, 3-12.

Wingate, M. (1962). Evaluation and Stuttering, Part I: Speech Characteristics of Young Children. Journal of Speech and Hearing Disorders, 106-119.

Wingate, M. (1970). Effect on Stuttering of Changes in Audition. J.Speech Hearing Res, 861-73.

Wylliey, S. (1894). Disorders of Speech. London: Oliver\&Boyel.

Yamamoto, K., \& Kawabata, H. (2011). Temporal Recalibration in Vocalization Induced by Adaptation of Delayed Auditory Feedback. Plos ONE, 1-8. http://dx.doi.org/10.1371/journal.pone.0029414.

Zinkin, N. (1968). Mechanisms of Speech. Monton \& Co.N.V., Publishers. Paris: The Hague.

\section{Glossary}

DAF: Delayed Auditory Feedback.

$\mathrm{SLP} / \mathrm{Ts}=$ speech-language pathologists/Therapists. 


\section{Macrothink

$\mathrm{SRB}=$ Simplified Regulated Breathing.

CAFET $=$ Computer-Aided Fluency Establishment Trainer.

\section{Copyright Disclaimer}

Copyright reserved by the author(s).

This article is an open-access article distributed under the terms and conditions of the Creative Commons Attribution license (http://creativecommons.org/licenses/by/3.0/). 